\title{
高感度フォースプレートを用いた 皮膚一材料間の摩擦係数推定に関する研究 A Study on Estimation Method of Friction Coefficient in Skin-Material Using High Sensitivity Force Plate
}

○正 廣瀬 圭 $^{* 1,2}$, 近藤 亜希子 ${ }^{1}$

Kiyoshi HIROSE $^{* 1,2}$, Akiko KONDO ${ }^{1}$

${ }^{* 1}$ 株式会社テック技販 TecGihan Co., Ltd. ${ }^{* 2}$ 同志社大学 Doshisha University

Key Words : Force, Moment, Velocity, Frequency, Fourier transform, Kalman filter

\section{1. 緒言}

繊維材料等の特性を把握することは衣服等の開発において非常に重要である。これまでに筆者らは，高 感度フォースプレートを用いてクーロン摩擦係数と粘性摩擦係数の推定法を構築し, 繊維材料の評価に用 いている. 本研究では, これまでに構築した摩擦係数推定法の性能を向上させるために, 周波数依存項を 導入し，さらに再現性のある計測情報を取得可能な装置を導入し，検証を行う。

\section{2. 摩擦係数推定}

高感度フォースプレート（触覚フォースプレート TF-2020, テック技販社）を 図 1 に示し, 高感度フォースプレートを搭載し, 高感度フォースプレートを搭 載し, 指と同等の柔らかさである模擬指（指紋あり，指紋なし）を装着した, 等速で平行に移動が可能な触覚計測装置を図 2 に示す. 摩擦推定法として, 管路の壁面に生じる抵抗を流体回路で表現すると, 形状, 流量, 周波数に依 存した抵抗が生じることを考慮し, 摩擦係数を垂直力に依存するクーロン摩擦, 速度に依存する粘性摩擦, 周波数に依存する周波数依存摩擦としてモデル化し た。ここで，指自身のもつ固有周波数，や速度，指一材料間の相互作用による 周波数のように複数の周波数に依存した摩擦が生じることから, 本研究では 3 つの周波数帯を考慮したモデルを構築した. 摩擦モデルを式(1)に示す.

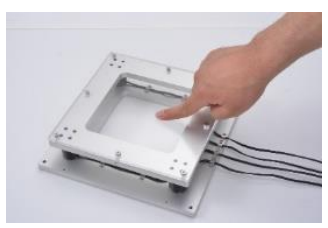

Fig.1 High sensitivity force plate

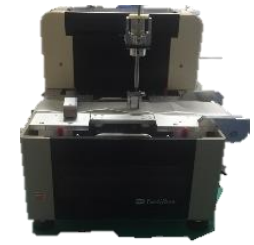

Fig.2 Tactile analysis system

$$
F=\mu F_{z}+\gamma v+\alpha_{1} \sin \left(\omega_{1} t+\beta_{1}\right)+\alpha_{2} \sin \left(\omega_{2} t+\beta_{2}\right)+\alpha_{3} \sin \left(\omega_{3} t+\beta_{3}\right)
$$

推定には拡張カルマンフィルタを用い, 周波数依存摩擦における周波数の初期值は予めフーリエ変換を 用いて計算・設定し，適用した． 2 種類の模擬指を用いて布材（ウール）の計測を行い，得られたフーリ エ変換の結果を図 3 に，摩擦力の結果（計測值と推定したパラメータを用いた推定值）を図 4 に示寸．周 波数依存抵抗の影響はフーリエ変換の結果からも確認できるが，本モデルを適用することにより，クーロ ン摩擦係数, 粘性摩擦係数における指紋の有無による違いが得られた.

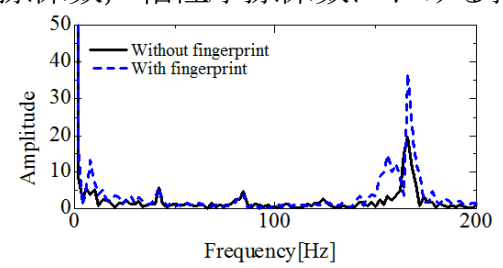

Fig.3 Frequency response
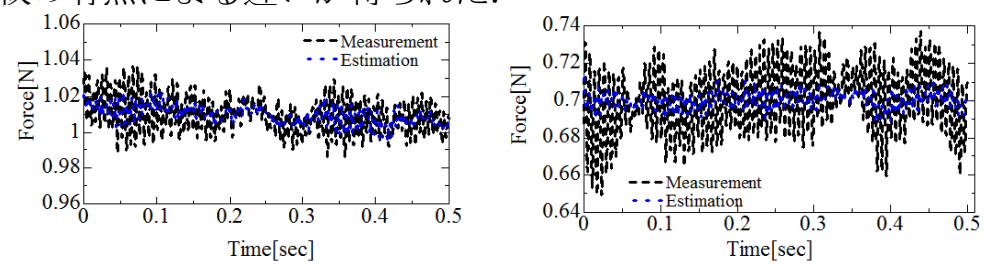

Fig.4 Friction force (Without fingerprint and with fingerprint)

文献

(1) 廣瀬圭, 近藤覀希子, “感度フォースプレートを用いた指一繊維材料間の摩擦係数推定法の開発に関する研究”, 日 本機械学会 2020 年度年次大会, (2019), J23103.

(2) 飯村或郎, 庄司 研二, 石井 誠一, 畑中 浩 “圧力測定孔による過渡特性”, 計測自動制御学会論文集, Vol. 22, No. 4 (1986), pp. 417-422. 